\title{
KESADARAN HUKUM MASYARAKAT DALAM PENCEGAHAN KEBAKARAN HUTAN DAN LAHAN DI KOTA DUMAI
}

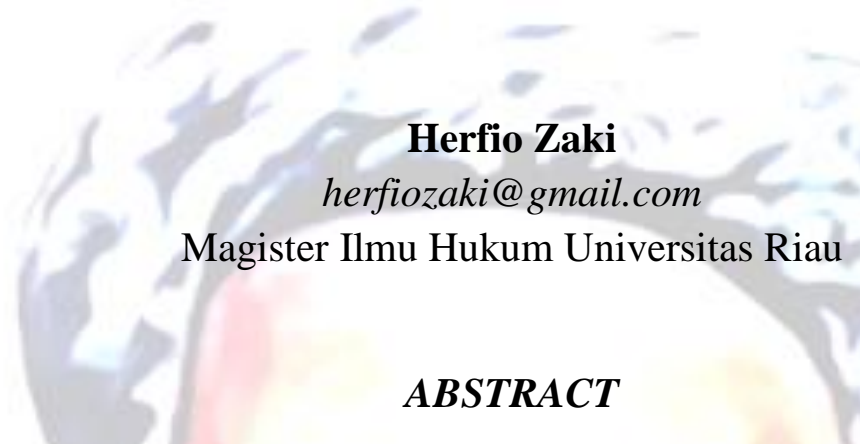

Legal awareness in the community as the personification of culture the laws of society that should keep implanted that of society discipline to to the law of could be increased further .In the community life there are always patterns of behavior or overtaken the applicable in communities with patterns of behavior is intended by existing norms ( rule ) law . This may cause an onset land burning problems and woods that specifically in the city is a social gap dumai so that at a particular time likely is conflict and social tensions could certainly disturb the way of the changes in the direction of the will of the people as .The state of is the case by because of laws created to expected can be used as guidelines in acting for the there is no legal awareness, so that there is no law tended to obedience.

Keywords : Legal Awareness, Prevention, fire

\begin{abstract}
ABSTRAK
Kesadaran hukum masyarakat sebagai penjelmaan dari budaya hukum masyarakat yang harus terus ditanamkan agar kepatuhan masyarakat terhadap hukum dapat terus ditingkatkan. Dalam kehidupan masyarakat senantiasa terdapat pola-pola perilaku atau kelakuan yang berlaku di masyarakat dengan pola-pola perilaku yang dikehendaki oleh norma-norma (kaidah) hukum. hal ini dapat menyebabkan timbulnya suatu masalah pembakaran lahan dan hutan yang terjadi khususnya di kota Dumai merupakan suatu kesenjangan sosial sehingga pada waktu tertentu cenderung terjadi konflik dan ketegangan-ketegangan sosial yang tentunya dapat mengganggu jalannya perubahan masyarakat sebagaimana arah yang dikehendaki. Keadaan demikian terjadi oleh karena adanya hukum yang diciptakan untuk diharapkan dapat dijadikan pedoman dalam bertindak bagi masyarakat tidak ada kesadaran hukum, sehingga cenderung tidak ada ketaatan hukum.
\end{abstract}

\section{Kata Kunci : Kesadaran Hukum, Pencegahan, Kebakaran}




\section{PENDAHULUAN}

Hutan merupakan sumberdaya alam yang mempunyai posisi yang sangat strategis dalam kehidupan berbangsa dan bernegara. Nilai penting sumberdaya tersebut kian bertambah karena hutan merupakan sumber hajat hidup orang banyak, akan tetapi akhir-akhir ini hutan di Indonesia mengalami degradasi dan juga deforestasi atau penghilangan hutan akibat pembukaan lahan yang cukup besar dan bahkan Indonesia merupakan negara dengan tingkat deforstasi paling parah di dunia. Salah satu penyebab deforestasi hutan adalah kebakaran hutan.

Sumber daya hutan dan lahan merupakan satu kesatuan alam yang paling ketergantungan (interdependence) yang sangat tinggi. Hutan sebagai suatu biotic community dan piramida kehidupan secara absolut membutuhkan abiotic cummunity, yakni lahan sebagai habitatnya. Adapun lahan sangat rentan terhadap bahaya erosi tanpa piramida kehidupan hutan. Selanjutnya hutan dan lahan merupakan habitat bagi piramida kehidupan lain seperti fauna dan flora yang dalam banyak hal sangat menopang kehidupan manusia, baik dari segi makanan maupun dari segi obat-obatan. Hubungan timbal balik antara biotic dan abiotic community tersebut, termasuk tingkah laku manusia, dikenal sebagai ekosistem yang terdiri dari sekelompok individu tumbuhan dan hewan yang berinteraksi dalam satu habitat.

Lembaga swadaya masyarakat Wahana Lingkungan Hidup (WALHI) telah melakukan perhitungan kerugian multidimensi dampak kebakaran hutan dan lahan serta kabut asap, salah satunya di provinsi Riau dengan kerugian ekonomi dan kebakaran hutan mencapai Rp 20 Triliun yaitu 2.398 Hektar cagar biosfer terbakar, 21.914 hektar lahan terbakar, 58.000 orang menderita gangguan pernafasan, ditambah pekerja dan anak sekolah aktifitas sehari-harinya terganggu.

Penyebab kebakaran hutan bisa terjadi karena faktor alami atau karena buatan manusia, baik yang disengaja maupun yang tidak disengaja, hal tersebut merupakan kurangnya kesadaran hukum masyarakat atas hukum dan kurangnya kesadaran masyarakat akan pelestarian hutan serta penjagaan lingkungan yang bersih.

Kota Dumai merupakan salah satu wilayah dari provinsi Riau dan juga 
wilayah di Indonesia yang juga terdapat banyak tindak pidana kebakaran hutan dan lahan, hal tersebut terjadi karena kurangnya kesadaran masyarakat dalam menjagadan melestarikan lingkungan dengan tidak membakar lahan atau membakar hutan untuk membuka lahan perkebunan. Kepolisian Resor Kota Dumai juga sudah melakukan sosialisasi kepada masyarakat untuk tidak membakar lahan, salah satunya adalah dengan membantu pemerintah dalam membuat kanal Blocking yaitu sebuah bendungan kecil yang dibangun disepanjang kanal untuk mencegah air pergi dengan cepat dan untuk mengantisipasi kebakaran hutan.

Tidak dapat dipungkiri bahwa fenomena kebakaran hutan telah menjadi suatu ancaman serius dan mendesak untuk ditanggulangi, terlebih dengan periodesasi yang hampir terjadi setiap tahun pembakaran hutan dan lahan merupakan kejahatan yang harus diperangi secara komprehensif oleh setiap pihak. Salah satu upaya untuk membalas pelaku pembakaran hutan atau lahan adalah dengan dilakukannya sosialisasi langsung ke masyarakat, penguatan aturan-aturan, pengawasan dengan membentuk tim patroli untuk kesetiap lokasi yang diduga rawan pembakaran hutan dan lahan, serta langkah dengan mengenakan hukuman pidana penjara dan denda semaksimal mungkin, untuk membuat jera dan menjadi pelajaran bagi yang melakukan perbuatan hingga terciptanya kesadaran hukum atas menjaga lingkungan dengan tidak membakar hutan dan lahan. Untuk itu sangat penting bagi masyarakat memahami bencana kebakaran tersebut, mengapa bisa bencana kebakaran terjadi dan apa dampaknya terhadap kehidupan manusia. Dengan memahami hal ini masyarakat akan memiliki kesadaran pentingnya mencegah terjadinya bencana kebakaran. Masyarakat seharusnya tidak merusak hutan dan menggunakan api dengan bijaksana, dan bertanggungjawab untuk mengendalikan api supaya tidak menyebar agar kejadian kebakaran hutan yang berulang-ulang setiap tahunnya dapat dicegah dan sedapat mungkin tidak terulang kembali.

Hambatan pada pengawasan dan penegakkan hukum terjadi pada lemahnya pengawasan oleh Pemda karena faktorfaktor seperti tidak adanya dukungan dana, keterbatasan SDM mengakibatkan praktek 
pembukaan lahan dengan bakar terus terjadi. Selain itu faktor yang menambah buruk disituasi di lapangan adalah tingkat kepedulian dan keterlibatan masyarakat yang dalam pencegahan, pengawasan dan penanggulangan kebakaran masih sangat minim. Secara garis besar upaya penegakkan hukum untuk menimbulkan efek jerah belum efektif untuk terciptanya kesadaran hukum masyarakat akan bahaya pembakaran hutan dan lahan tersebut.

Berdasarkan uraian tersebut, maka penulis tertarik mengkaji dan membahas dengan judul "Kesadaran Hukum Masyarakat Dalam Pencegahan Kebakaran Hutan Dan Lahan Di Kota Dumai”.

METODE PENELITIAN

Untuk dapat mencapai tujuan yang diharapkan maka penelitian ini menggunakan jenis penelitian Observasi (Obeservation Research ). Sedangkan dilihat dari sifat penelitiannya adalah menggunakan Diskriptif analitis. Tempat penelitian ini dilakukan langsung pada wilayah kota Dumai. Sebagai jenis data dalam penelitian Kesadaran Hukum Masyarakat dalam Pencegahan Kebakaran Hutan dan Lahan Di Kota Dumai adalah : a. Data Primer adalah data utama yang diperoleh dari data Masyarakat tentang Kesadaran Dalam Pencegahan Kebakaran Hutan Dan Lahan Di Kota Dumai.

b. Data sekunder adalah data yang diperoleh dari buku-buku literatur yang mendukung pokok masalah tentang Kesadaran Hukum Masyarakat Dalam Pencegahan Kebakaran Hutan Dan Lahan. Data sekunder disamping buku-buku juga dapat berupa skripsi, tesis, disertasi, jurnal, surat kabar, makalah seminar dan ada juga datadata pendukung lainnya.

Penulisan ini berkaitan dengan Kesadaran Hukum Masyarakat Dalam Pencegahan Kebakaran Hutan Dan Lahan Di Kota Dumai, untuk itu dilakukan lah survai lapangan dengan terlebih dahulu untuk menentukan populasi dan sampel yang akan diteliti. Selanjutnya dilaksanakan riset untuk mendapatkan data dan keterangan yang diperlukan.

Populasi dapat dikatakan lain sebagai berikut, pertama, sekumpulan unsur atau elemen yang menjadi objek penelitian dan elemen populasi itu sendiri merupakan suatu analisis; kedua, 
sekumpulan objek, baik manusia, gejala, benda atau peristiwa; keempat, semua individu untuk siapa kenyataan-kenyataan yang diperoleh dari sampel itu hendak digeneralisasikan; kelima, jumlah keseluruhan unit analisis yang ciri-cirinya akan diduga.

Dari pengertian diatas dapat disimpulkan bahwa yang dimaksud dengan populasi adalah keseluruhan objek penelitian yang terdiri dari manusia, benda, gejala atas peristiwa, sebagai sumber data yang memiliki karakteristik tertentu dalam suatu penelitian. Populasi dalam penelitian ini adalah mengumpulkan data baik itu berupa tertulis maupun lisan atau suatu pernyataan dan keterangan yang terkait dengan Kesadaran Hukum Masyarakat Dalam Pencegahan Kebakaran Hutan Dan Lahan Di Kota Dumai.
Mengingat besarnya populasi, maka penelitian ini tidak meneliti semua populasi, karena sedikit orang yang mengetahui tentang Kesadaran Hukum Masyarakat Dalam Pencegahan Kebakaran Hutan Dan Lahan Di Kota Dumai. Untuk itu, dengan meneliti sebagaian dari populasi diharapkan hasil yang diperoleh akan memberikan gambaran sesuai dengan populasi yang bersangkutan. Penentuan sampel penelitian ini menggunakan metode Purposive sampling yang artinya pengambilan diadakan dengan cara pengambilan subjek didasarkan pada tujuan tertentu, yaitu karena hanya orangorang tertentu saja yang mengetahui tentang Kesadaran Hukum Masyarakat Dalam Pencegahan Kebakaran Hutan Dan Lahan Di Kota Dumai. Adapun teknik penentuan responden yang digunakan adalah non random purposive sumpling.

Yang menjadi responden dalam penelitian ini adalah :

\begin{tabular}{|l|l|l|}
\hline No & \multicolumn{1}{|c|}{ Responden } & \multicolumn{1}{c|}{ Jumlah } \\
\hline 1 & $\begin{array}{l}\text { Kepada Desa atau lurah didaerah } \\
\text { kota Dumai }\end{array}$ & 1 orang \\
\hline 2 & Kepala Unit Reskrim I & 1 orang \\
\hline 3 & Walhi & 1 orang \\
\hline 4 & Masyarakat & 30 orang \\
\hline
\end{tabular}

Sumber Data : Kota Dumai 2018. 
Sebagai alat pengumpul data dalam penelitian Kesadaran Hukum Masyarakat Dalam Pencegahan Kebakaran Hutan Dan Lahan Di Kota Dumai ini adalah :

a. Kuisioner, yaitu alat pengumpul data yang dilakukan dengan cara peneliti membuat daftar pertanyaan secara tertutup atau terbuka kepada responden atau sampel. Daftar isi pertanyaan ini hanya berdasarkan tentang Kesadaran Hukum Masyarakat Dalam Pencegahan Kebakaran Hutan Dan Lahan Di Kota Dumai.

b. Wawancara, yaitu pengumpulan data yang dilakukan dengan cara menulis mengadakan tanya jawab secara langsung kepada siapa yang menjadi responden tentang Kesadaran Hukum Masyarakat Dalam Pencegahan Kebakaran Hutan Dan Lahan Di Kota Dumai tersebut.

Adapun analisis data yang digunakan adalah metode analisis data kualitatif, yaitu proses penyusunan, mengkategorikan data kualitatif, mencari pola atau tema dengan maksud memahami maknanya. Data kualitatif terdiri atas katakata yang tidak diolah menjadi angkaangka. Salah satu usaha dalam analisis data kualitatif adalah reduksi data, artinya laporan-laporan itu perlu direduksi, dirangkum,dipilih hal-hal yang pokok, difokuskan pada hal-hal yang penting, disusun lebih sistematis sehingga lebih mudah dikendalikan. Jika menggunakan analisis kualitatif, maka data yang telah terkumpul harus dipisah-pisahkan menurut kategori masing-masing dan kemudian ditafsirkan dalam usaha mencari jawaban masalah penelitian.

Data-data yang terkumpul dari penelitian ini kemudian saling dihubungkan satu dengan yang lainnya dan disusun secara sistematis dalam bentuk laporan, kemudian disimpulkan secara induktif, yaitu cara mengambil kesimpulan dengan pokok pikiran berada di akhir paragraf.

\section{HASIL PENELITIAN}

\section{A. Kesadaran Hukum Masyarakat Dalam Pencegahan Kebakaran Hutan dan Lahan di Kota Dumai}

Pemahaman masyarakat tentang pentingnya akan hutan didasarkan pada pengetahuan masyarakat pada saat menjalankan kehidupannya disekitar hutan. Adanya pemahaman masyarakat tentang arti hutan sudah sebagian besar mengetahui secara umum apa itu hutan. Pemahaman tentang hutan memiliki arti berbeda-beda tetapi sebagian besar 
menyebutkan hutan adalah tempat tumbuhnya pohon-pohon besar, tempat berkembangbiak hewan liar, suatu kawasan yang ditumbuhi oleh tumbuhtumbuhan dengan keragaman yang tinggi dan hutan merupakan lahan yang statusnya dimiliki oleh Negara. Sebagian masyarakat yang tidak mengerti tentang hutan karena masih ada masyarakat yang tidak memiliki kepentingan pada kawasan hutan. Faktor ini menjadi tingkat pengetahuan tentang hutan menjadi rendah karena tidak pernahnya masuk hutan, tidak pernah mendapatkan pengetahuan atau pembelajaran dan tidak pernah sama sekali turut serta pada kegiatan kehutanan.

\section{Bencana pembakaran hutan dan} lahan merupakan suatu permasalah yang sangat serius yang harus dihadapi bangsa Indonesia hampir setiap tahun pada musim kemarau. Kebakaran yang terjadi tidak hanya pada lahan kering tetapi juga pada lahan basah (terutama lahan gambut). Kebakaran pada hutan dan lahan gambut jauh lebih sulit ditangani dibandingkan dengan kebakaran yang terjadi dihutan tanah mineral atau dataran tinggi, oleh karena itu perlu adanya kesadaran hukum kepada masyarakat akan patuh dan tidak melakukan pembakaran terhadap hutan dan lahan khususnya di kota dumai.
Ketentuan mengenai kebakaran hutan/pembakaran hutan didalam undangundang - kehutanan sebenarnya tidak memberikan perhatian yang memamdai bagi upaya penanggulangan kebakaran, karena larangan membakar hutan yang terdapat dalam undang-undang kehutanan ternyata dapat dimentahkan untuk tujuantujuan khusus sepanjang mendapat izin dri pejabat yang berwenang. Sementara ketentuan dalam peraturan pemerintah (PP) Nomor 4 tahun 2001 memperkecil interepretasi penggunaan Pasal 10 dalam PP Nomor 45 tentang tindakan penegakan hukumnya, artinya tindakan perlindungan hutan dan tindakan perlindungan hutan dari tindakan perbakaran akan diberlakukan bagi mereka pelaku yang tidak memiliki izin atau surat pula, ketentuan sanksi bagi pembakaran hutan hanya diberlakukan sanksi administrasi sebagaimana diatur dalam Pasal 25 dan 27 UU nomor 23 tahun 1997 tentang pengelolaan lingkungan hidup.

Lahan menginstruksikan kepada pemimpin daerah untuk meningkatkan pengendalian Karhutla melalui Pencegahan, pemadaman dan penanganan pasca karhutla. Perubahan secara mendasar terkait penambahan jumlah institusi yang dilibatkan. Institusi-institusi 
yang baru dimasukkan ini terkait peran dan fungsinya dalam rangka menata aspek sosial terkait dengan pendidikan dan kesehatan. Selain itu terkait dengan konflik lahan maupun pembangunan infrastruktur. Akan tetapi yang terkait dengan pembangunan desa belum termasuk dalam institusi pemerintah yang terlibat dalam pengendalian Karhutla. Secara mendasar bahwa kedepan untuk pengendalian Karhutla yang berkelanjutan semestinya melibatkan pemerintah desa. Tegaknya suatu peraturan hukum baru akan menjadi kenyataan bilamana didukung oleh adanya kesadaran hukum segenap warga masyarakat. Kesadaran bagi berlakunya hukum adalah dasar bagi dilaksanakannya hukum itu sendiri. kesadaran hukum itu berakar didalam masyarakat, itu merupakan abstraksi yang lebih rasional daripada perasaan yang hidup didalam masyarakat

Menurut Dinas Kehutanan Provinsi

Riau, Disamping melakukan pencegahan, pemerintah juga melakukan penanggulangan melalui berbagai kegiatan antara lain :

1. Memberdayakan posko-posko kebakaran hutan di semua tingkat, serta melakukan pembinaan mengenai hal-hal yang harus dilakukan selama siaga I dan II.

2. Mobilitas semua sumberdaya (manusia, peralatan \& dana) di semua tingkatan, baik di jajaran Departemen Kehutanan maupun instansi lainnya, maupun perusahaan-perusahaan.

3. Meningkatkan koordinasi dengan instansi terkait di tingkat pusat melalui PUSDALKARHUTNAS dan di tingkat daerah melalui PUSDALKARHUTDA Tk I dan SATLAK kebakaran hutan dan lahan.

4. Meminta bantuan luar negeri untuk memadamkan kebakaran antara lain: pasukan BOMBA dari Malaysia untuk kebakaran di Riau, Jambi, Sumsel dan Kalbar; Bantuan pesawat AT 130 dari Australia dan Herkulis dari USA untuk kebakaran di Lampung; Bantuan masker, obat-obatan dan sebagainya dari negara-negara Asean, Korea Selatan, Cina dan lain-lain.

Problema hukum yang berlaku dewasa ini adalah masih rendahnya kesadaran hukum masyarakat. Akibatnya, banyak terjadi pelanggaran hukum yang sesungguhnya tidak perlu terjadi misalnya melakukan pembakaran lahan dan hutan demi kepentingan sendiri tanpa 
mempedulikan masyarakat banyak akan mendapat dampaknya. Kesadaran hukum dapat diartikan sebagai persepsi individu atau masyarakat terhadap hukum. Persepsi tersebut mungkin sama ataupun tidak sama dengan hukum yang berlaku. Hukum di sini merujuk pada hukum yang berlaku dan hukum yang dicita-citakan. Dengan demikian hukum di sini meliputi hukum tertulis dan hukum tidak tertulis. Misalnya hukum Islam dan hukum adat, walaupun kedua hukum tersebut tidak memiliki bentuk formal (tertulis) dalam lingkup hukum nasional, akan tetapi hukum tersebut seringkali dijadikan dasar dalam menentukan suatu tindakan. Kesadaran hukum berkaitan dengan nilai-nilai yang tumbuh dan berkembang dalam suatu masyarakat.

Menurut Soejono Soekanto menyatakan ada 4 indikator yang membentuk kesadaran hukum yang secara berurutan (bertahap demi tahap) yaitu :

1. Pengetahuan hukum, pengetahuan seseorang berkenaan dengan perilaku tertentu yang diatur oleh hukum tertulis, yakni tentang apa yang dilarang dan apa yang diperbolehkan

2. Pemahaman hukum, sejumlah informasi yang dimiliki oleh seseorang mengenai isi dari aturan (tertulis),

yakni mengenai isi, tujuan, dan manfaat dari peraturan tersebut.

3. Sikap hukum (Legal attitude), merupakan suatu kecenderungan untuk menerima atau menolak hukum karena adanya penghargaan atau keinsyafan bahwa hukum tersebut bermanfaat bagi kehidupan manusia. Dalam hal ini sudah ada elemen apresiasi terhadap aturan hukum.

4. Pola perilaku hukum, tentang berlaku atau tidaknya suatu aturan hukum dalam masyarakat. Jika berlaku suatu aturan hukum, sejauh mana berlakunya itu dan sejauh mana masyarakat mematuhinya.

B. Kendala Dalam Terciptanya Kesadaran Hukum Masyarakat Dalam Pencegahan Kebakaran Hutan Dan Lahan Di Kota Dumai

Penegakan supremasi $r$ hukum
adalah sebuah upaya manusia untuk
menggapai keteraturan atau ketertiban
yang dibutuhkan. Dalam penegakan
hukumnya, yang pokok adalah
mensinergikan ketiga pilarnya yaitu
undang-undang, aparat penegak hukum,
dan budaya hukum massyarakatnya.
Kesadaran hukum masyarakat sebagai
penjelmaan dari budaya hukum


masyarakat yang harus terus ditanamkan agar kepatuhan masyarakat terhadap hukum dapat terus ditingkatkan. Peranan kesadaran hukum masyarakat sebagai tujuan hukum itu sendiri adalah menjamin kepastian dan keadilan. Dalam kehidupan masyarakat senantiasa terdapat pola-pola perilaku atau kelakuan yang berlaku di masyarakat dengan pola-pola perilaku yang dikehendaki oleh norma-norma (kaidah) hukum. hal ini dapat menyebabkan timbulnya suatu masalah berupa kesenjangan sosial sehingga pada waktu tertentu cenderung terjadi konflik dan ketegangan-ketegangan sosial yang tentunya dapat mengganggu jalannya perubahan masyarakat sebagaimana arah yang dikehendaki. Keadaan demikian terjadi oleh karena adanya hukum yang diciptakan untuk diharapkan dapat dijadikan pedoman dalam bertindak bagi masyarakat tidak ada kesadaran hukum, sehingga cenderung tidak ada ketaatan hukum.

\footnotetext{
Membina kesadaran hukum adalah suatu tuntutan perubahan sosial yang dewasa ini menjadi perhatian pemerintah dan telah digalakkan dalam usaha pembangunan. Sejak awak pemerintahan orde baru secara jelas dan sistematis
}

dituangkan dalam Ketetapan Majelis Permusyawaratan Rakyat (MPR) Nomor IV/MPR/1978 Mengenai Garis-Garis Besar Haluan Negara (GBHN) dalam hal hukum, tertib hukum dan penegakan hukum. penegasan ini dirumuskan sebagai berikut :

1. Guna meningkatkan ketertiban dan kepastian hukum dalam mengayomi masyarakat, yang merupakan syarat bagi terciptanya stabilitas nasional yang mantap, maka aparatur pemerintah pada umumnya dan aparatur penegak hukum pada khususnya perlu terus menerus dibina dan dikembangkan untuk peningkatan kemampuan serta kewibawaannya.

2. Pembangunan dan pembinaan di bidang hukum diarahkan agar hukum mampu memenuhi kebutuhan sesuai dengan tingkat kemajuan pembangunan, sehingga dapat diciptakan ketertiban dan kepastian umum.

3. Usaha-usaha penertiban badan-badan penegak hukum perlu dilanjutkan

4. Usaha peningkatan kemampuan dan kewibawaan aparat penegak hukum perlu dilanjutkan 
5. Meningkatkan kesadaran hukum hukum dan nilai-nilai sosial. Apabila sehingga masyarakat menghayati hak ditinjau dari teori-teori modern tentang dan kewajibannya hukum dan pendapat para ahli hukum

6. Meningkatkan pembinaan sikap para pelaksana penegak hukum ke arah tentang sifat mengikat dari hukum, timbul bermacam permasalahan. Salah satu tegaknya hukum, keadilan dan persoalan yang timbul adalah mengenai pembinaan perlindungan harkat dan martabat manusia, ketertiban dan kepastian hukum sesuai dengan Undang-undang Dasar 1945.

Tegaknya suatu peraturan hukum baru akan menjadi kenyataan bilamana didukung oleh adanya kesadaran hukum segenap warga masyarakat. Kesadaran bagi berlakunya hukum adalah dasar bagi dilaksanakannya hukum itu sendiri. adanya suatau jurang pemisah antara asumsi-asumsi tentang dasar keabsahan hukum tertulis, serta kenyataan dari pada dipatuhinya hukum tersebut. Terdapat suatu pendapat yang menyatakan bahwa mengikatnya hukum terutama tergantung pada keyakinan seseorang. Hal inilah yang dinamakan toeri rechtsbwqustzjin.

Sudikno mertokusumo dalam buku Sosiologi hukum tidak akan membiarkan hukum bekerja dengn menyeluruh, melarang, membuat ancaman sanksi dan sebagainya, tanpa mengamati sekalian sisi yang terlibat dalam bekerjanya hukum tersebut. Disisi lain dapat juga dipertanyakan mengapa rakyat harus patuh, dari mana negara mempunyai kekuasaan untuk memaksa, apakah rakyat tidak boleh menolak serta faktor-faktor apakah yang berhubungan dengan kepatuhan.

Masalah kesadaran hukum rampai ilmu hukum mengatakan kesadaran hukum adalah kesadaran tentang apa yang seyogyanya kita lakukan atau perbuat atau yang seyogyanya tidak kita lakukan atau perbuat terutama terhadap orang lain. Kesadaran hukum mengandung sikap toleransi. Dapat disimpulkan bahwa kesadaran hukum merupakan cara pandang masyarakat terhadap hukum itu. Apa yang seharusnya dilakukan dan tidak dilakukan terhadap hukum, serta penghormatan terhadap hak-hak orang lain. Ini berarti bahwa dalam kesadaran hukum mengandung sikap toleransi.

termasuk didalam ruang lingkup persoalan 
Upaya pencegahan dan meningkatkan efektivitas dan optimasi penanggulangan yang telah dilakukan kegiatan pencegahan dan penanggulangan selama ini ternyata belum memberikan kebakaran hutan perlu upaya penyelesaian hasil yang optimal dan kebakaran hutan masalah yang terkait dengan faktor-faktor masih terus terjadi pada setiap musim tersebut.

kemarau. Kondisi ini disebabkan oleh berbagai faktor antara lain:

1. Kemiskinan dan ketidak adilan bagi masyarakat pinggiran atau dalam kawasan hutan

2. Kesadaran semua lapisan masyarakat terhadap bahaya kebakaran masih rendah.

3. Kemampuan aparatur pemerintah khususnya untuk koordinasi, memberikan penyuluhan untuk kesadaran masyarakat, dan melakukan upaya pemadaman kebakaran semak belukar dan hutan masih rendah.

4. Upaya pendidikan baik formal maupun informal untuk penanggulangan kebakaran hutan belum memadai.

Hasil identifikasi dari serentetan kebakaran hutan menunjukkan bahwa penyebab utama kebakaran hutan adalah faktor manusia dan faktor yang memicu meluasnya areal kebakaran adalah kegiatan perladangan, pembukaan HTI dan perkebunan serta konflik hukum adat dengan hukum negara, maka untuk
Penanganan kebakaran hutan dan lahan masih mengalami beberapa kendala dalam implementasinya pada masyarakat, berdasarkan indentifikasi yang dilakukan pemerintah setidaknya ada empat masalah besar yang menghambat upaya pencegahan dan penanganan kebakaran hutan dan lahan antara lain :

1. Berkaitan dengan belum adanya anggaran khusus yang digunakan untuk pencegahan dan mengadakan sarana prasarana pemadam terhadap kebakaran hutan dan lahan

2. Peraturan Meteri dalam Negeri Nomor 21 tahun 2011 tentang pedoman Pengelolaan Keuangan Daerah. Peraturan tersebut telah menghambat upaya daerah dalam mencegah kebakaran hutan diwilayah dengan menggunakan dana APBD, aturan tersebut hanya memberikan izin kepada daerah untuk memanfaatkan APBD saat kondisi tanggap darurat sudah ditetapkan. 
3. Keterbatasan akses masyarakat tetapi betapa banyak dan seringnya terhadi terhadap teknologi pengolahan lahan nuansa kekerasan yang secara langsung tanpa bakar, masalah tersebut dengan - mobilitas massa dan atau membuat praktek pengolahan lahan kekerasan secara komunal telah mengadili tanpa membakar hutan susah dan menghakimi sendiri para pelaku dihilangkan.

tindak kriminal terutama yang bersentuhan

4. Penolakan dari masyarakat dalam pemecahannya dalam mengatasi kebakaran hutan dan lahan.

\section{KESIMPULAN}

Pemahaman masyarakat tentang pentingnya akan hutan didasarkan pada pengetahuan masyarakat pada saat menjalankan kehidupannya disekitar hutan. Bencana pembakaran hutan dan lahan merupakan suatu permasalah yang sangat serius yang harus dihadapi bangsa Indonesia hampir setiap tahun pada musim kemarau. Kebakaran yang terjadi tidak hanya pada lahan kering tetapi juga pada lahan basah (terutama lahan gambut). Bercermin dari kenyataan tersebut, maka bisa ditarik kedalam suatu sorotan bahwa kultur masyarakat Indonesia memanglah bukan masyarakat yang sadar hukum. sehingga semakin terbukti tatkala kita dengan mudah menyaksikan bukan saja para aparat penegak hukum yang melakukan penyalahgunaan kekuasaan, langsung dengan masyarakat, sehingga pembakaran adalah sisi lain cara masyarakat mengimplementasikan arti sebuah keadilan atau cara yang tepat dalam mereka berhukum, karena institusi Negara tidak lagi dianggap sebagai tempat dalam memproses dan menemukan keadilan.

Konsep hubungan sebab akibat dalam hukum pidana merupakan bentuk pembuktian apakah benar suatu tindakan tertentu masuk kategori tindak pidana baik telah menimbulkan kerugian (delik Meteril) maupun belum menimbulkan kerugian (delik formil). Undang-undang yang mengatur tentang pembakaran hutan dan lahan hanya menganut ajaran melawan hukum materil dimana ada pidana ketika terjadi kerugian. Ajaran ini sejatinya tidak hanya menjadi penghalang dalam menjerat pelaku sebab baru ada pidana ketika terjadi kesalahan (delik Materil). Padahal dampak dari kebakaran hutan dan lahan bersifat masif dan melintasi batas Negara. 
Sebagai institusi yang berwenang, berupa kesenjangan sosial sehingga pada kepolisian telah melakukan proses hukum waktu tertentu cenderung terjadi konflik terhadap perorangan dan perusahaan dan ketegangan-ketegangan sosial yang pelaku pembakaran hutan. Dari data yang dirilis oleh pihak kepolisian menyatakan tindakan kepolisian setidaknya telah menunjukkan adanya upaya penegakan hukum. akan tetapi timbul pertanyaan yang menyatakan instrumen hukum apa yang hendak dipakai dalam menindak pelaku pembakaran hutan ketika terdapat tiga undang-undang yang mengatur, kondisi ini mirip dengan ajaran utilitarinisme Jeremy bentham untuk melakukan penegakan hukum dan menciptakan keadilan. tentunya dapat mengganggu jalannya perubahan masyarakat sebagaimana arah yang dikehendaki. Keadaan demikian terjadi oleh karena adanya hukum yang diciptakan untuk diharapkan dapat dijadikan pedoman dalam bertindak bagi masyarakat tidak ada kesadaran hukum, sehingga cenderung tidak ada ketaatan hukum.

\section{REFERENSI}

Kesadaran hukum masyarakat sebagai penjelmaan dari budaya hukum masyarakat yang harus terus ditanamkan agar kepatuhan masyarakat terhadap hukum dapat terus ditingkatkan. Peranan kesadaran hukum masyarakat sebagai tujuan hukum itu sendiri adalah menjamin kepastian dan keadilan. Dalam kehidupan masyarakat senantiasa terdapat pola-pola perilaku atau kelakuan yang berlaku di masyarakat dengan pola-pola perilaku yang dikehendaki oleh norma-norma (kaidah) hukum. hal ini dapat menyebabkan timbulnya suatu masalah

\section{A. Buku}

Absori, 2014, Hukum Penyelesaian

Lingkungan Hidup : sebuah Model Penyelesaian

Sengketa Lingkungan

Hidup Dengan Pendekatan

Partisipatif, Surakarta, Muhammadiyah Press

Bambang Prabowo Soedarso, 2008, Hukum Lingkungan dalam Pembangunan Terlanjutkan ,Cintya Press, Jakarta.

Muhammad Akib, 2011, Penegakan Hukum Lingkungan Dalam Perspektif HolistikEkologis, Bandar Lampung : Universitas Lampung 
Prasetyo, Teguh, 2011, "Hukum Pidana”, Edisi Revisi, Raja Grafindo Persada. Jakarta. 2013, Hukum dan Undang-Undang Perkebunan, Cetakan I, Unjung Berung, Bandung.
Berbasis Local Wisdom, Fakultas Hukum, Universitas

Muhammadiyah Riau, Seminar Nasional Hukum Universitas Negeri Semarang Volume 2 Nomor 1, 93-108.
Ridwan HR,2013,Hukum Administrasi Negara, PT. Raja Grafindo Persada, Jakarta.

Sadjijono, 2010,Memahami Hukum Kepolisian, PT Lakabang Presindo, Yogyakarta.

Soerjono Soekanto dan Sri Mamudji, 2010, Penelitian Hukum Normatif (Suatu Tinjauan Singkat), Rajawali Pres, Jakarta.

Sowieryo,2011, Tindak Pidana Ringan, Bandung : Alumni

Sukanda Husin, 2009, Penegakan Hukum Lingkungan Indonesia, Jakarta : Sinar Grafika.

\section{B. Jurnal, Skripsi atau Tesis}

Dinas Kehutanan Provinsi Riau (DKPR), 2015, Profil Penanganan Kebakaran Hutan di Provinsi Riau, Pekanbaru, Dinas Kehutanan Provinsi Riau

Elviandri, 2016, Revitalisasi Ideologi Pancasila dalam Penegakan Hukum Kebakaran Hutan: Meneguhkan Otentisitas Hukum Keindonesiaan
Erdiansyah, 2014-2015, Implementasi Pertanggungjawaban Pidana Korporasi Pembakaran Hutan Dan Lahan Di Provinsi Riau, Jurnal Ilmu Hukum, Fakultas Hukum Universitas Riau, Volume 4 No.3 September-Januari.

Sharah Marsela, 2016, Penyidikan Terhadap Tindak Pidana Perambahan Kawasan Hutan Cagar Biosfer Giam Siak Kecil Oleh Kepolisian Resor Bengkalis Berdasarkan UndangUndang Nomor 18 Tahun 2013 Tentang Pencegahan Dan Pemberantasan Perusakan Hutan, JOM Fakultas Hukum Volume III No 2, oktober.

\section{Internet}

https://foresteract.com/pengertianhutan/, diakses pada tanggal 18 juli 2018.

Kementerian Lingkungan Hidup dan Kehutanan (KLHK), 2016, Karhutla Monitoring Sistem, diakses 8 November 2018 


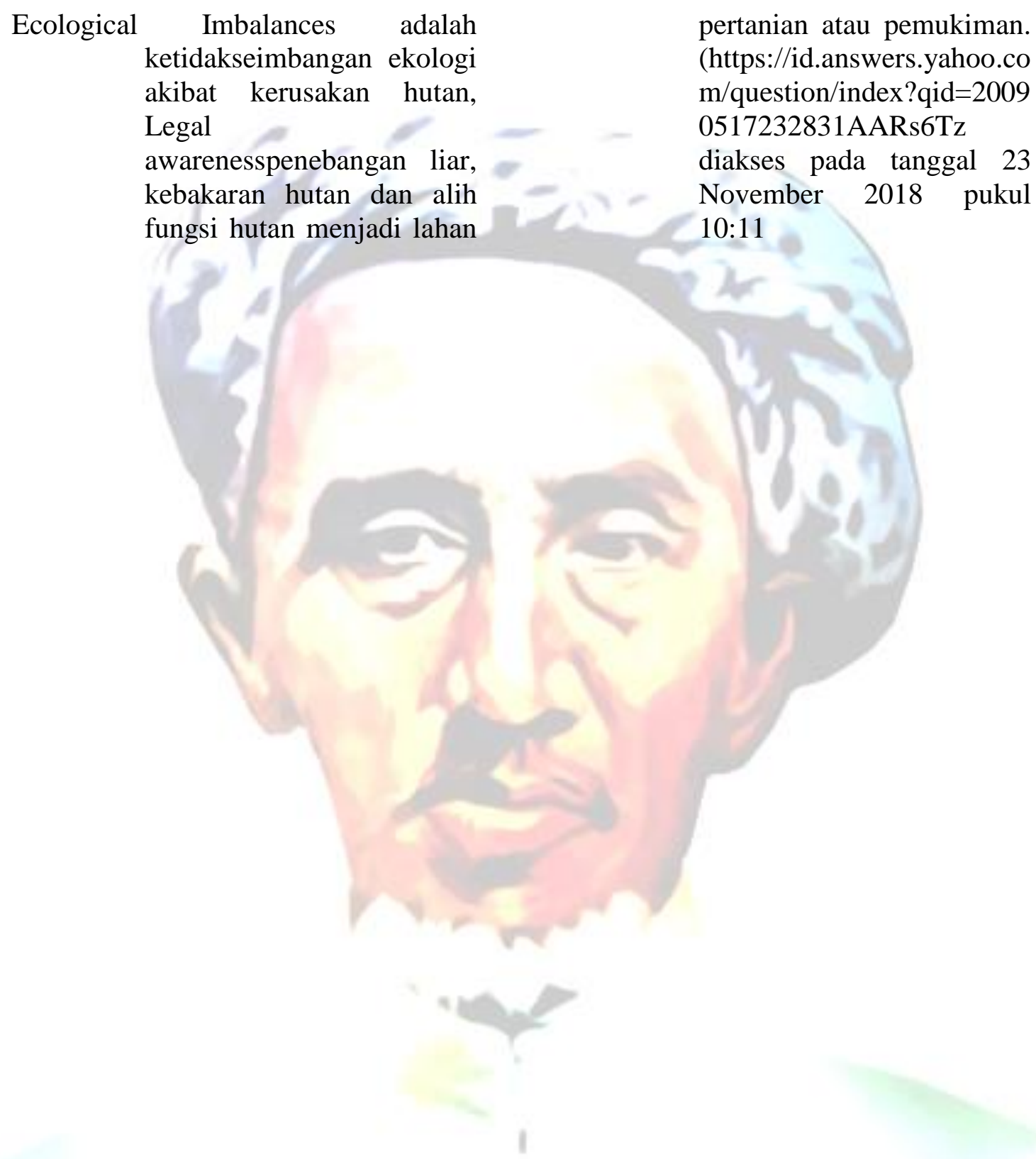

